SUCCESSORS AND PARALLELS IN EAST AND WEST 


\section{COURT AND CAPITAL IN BYZANTIUM}

\section{Paul Magdalino}

The relationship between court and capital is perhaps what best defines the structural singularity of any court society, since it is infinitely variable. A court can exist without a single fixed capital, though such independent self-sufficiency is the exception in the long term, and a pure court that stays put long enough will put down roots and become the nucleus of a capital. A royal capital presupposes a royal court, but not necessarily at its heart or in permanent residence. Most court societies fall somewhere within the spectrum between total integration and total detachment, and the longer they last the greater the range of permutations they are likely to exhibit. The Byzantine imperial court, which lasted over one thousand years, did not have a static relationship with the empire's capital, Constantinople. It left the city when the emperor went on campaign, or retired for the summer to a suburban palace on the Bosphoros. Within the city, it bilocated during the twelfth century between the downtown Great Palace and the semisuburban Blachernae, before withdrawing completely to the latter. The Latin conquest of 1204 not only forced the court out of Constantinople on a temporary basis, but also caused it to splinter into three centres, in northern Greece, western Asia Minor, and the Pontos. The courts in northern Greece and Trebizond survived the recovery of Constantinople by their western Anatolian rival in 1261. The restored empire of the Palaiologoi itself became progressively split by civil wars and divisions within the ruling dynasty, and provincial courts emerged at Thessaloniki and Mistra, not to mention the more ephemeral centres at Didymoteichon, Adrianople and Selymbria.

However, all these developments stemmed from a very strong bond between court and capital. On the scale of possible permutations, the only monarchy that came as close or closer to a model of total integration was the regime from which Byzantium derived, namely imperial Rome. The Roman imperial monarchy was the creation of a city that was already the capital of an empire, and for the first three hundred years of its existence it remained firmly rooted in the civic institutions and topography of that Eternal City. With Diocletian and the 
Tetrarchy, government devolved from Rome to a number of subsidiary capitals, each of which housed its own court. Yet it is significant that each of these Tetrarchic 'Romes from Rome', at Trier, Milan, Nicomedia, Thessalonica, and elsewhere, replicated not only the emperor's palatine residence, but also the unique juxtaposition of the Palatine complex and the Circus Maximus. ${ }^{1}$ Thus every Tetrarchic palace came complete with an adjoining hippodrome where the emperor and his entourage joined the local populus Romanus to watch the games from the imperial box. When Constantine ended the Tetrarchy, he adopted the same model in the foundation of Constantinople, to which he and his successors added other distinctive Roman features: a Senate, a Capitolium, imperial fora with triumphal columns and triumphal arches, an array of classical statues pilfered from other cities, huge public baths, a massive infrastructure of grain and water supply, and, eventually but inevitably, the title of New Rome. ${ }^{2}$

With time, Byzantium became more and more of an oriental despotism, but the Byzantine imperial court remained encased in the husks of Roman civic tradition. At its core it was a secretive, private household screened and staffed by eunuchs, but on the outside it was a hierarchy of public officials which ramified beyond the Palace, and whose upper ranks, at least, were always known as the Senate. ${ }^{3}$ The essential activity of the court was the performance of ritual: an elaborate round of ceremonies designed to elevate and celebrate the emperor as the image of God on earth, alternately occluded and highlighted, moving and motionless, in a variety of settings with a many-layered apparatus of attendants, partitions, vestments, lights, and pregnant silences punctuated by rousing sounds. ${ }^{4}$ But court ceremonial reached out as well as looked inward. It honoured all who took part by display-

${ }^{1}$ See John H. Humphrey, Roman Circuses. Arenas for Chariot Racing (London 1986) passim and pp. 636-637.

${ }^{2}$ See in general Gilbert Dagron, Naissance d'une capitale, Constantinople et ses institutions de 330 à 451 (Paris 1974); Cyril Mango, Le développement urbain de Constantinople (IV $-V I I^{F}$ siècles ) 3rd ed. (Paris 2004); Sarah Bassett, The Urban Image of Late Antique Constantinople (Cambridge 2004); Franz A. Bauer, Stadt, Platz und Denkmal in der Spätantike. Untersuchungen zur Ausstattung des öffentlichen Raums in den spätantiken Städten Rom, Konstantinopel und Ephesos (Mainz 1996).

${ }^{3}$ See Michael McCormick, 'Emperor and Court', in: The Cambridge Ancient History, XIV. Late Antiquity: Empire and Successors, A.D. 425-600, Averil Cameron; Bryan Ward-Perkins, Michael Whitby, eds. (Cambridge 2000) pp. 135-163.

${ }_{4}^{4}$ Paul Magdalino, The Empire of Manuel I Komnenos, 1143-1180 (Cambridge 1993) pp. 237-248, with bibliography. 
ing their status within the hierarchy of proximity to the sovereign. It maintained the bond between court and capital that had been emphasised in the foundation of Constantinople, by linking the closed spaces of the inner Palace to the open spaces of the City. Above all, it animated the enduring architectural association between the Palace and the Hippodrome that Constantine had reproduced from Rome via the Tetrarchic capitals.

The main source for this picture of the Byzantine court is the Book of Ceremonies, a voluminous compilation commissioned by the emperor Constantine VII between 945 and 959, and added to after his death. ${ }^{5}$ Six chapters describe the procedure for the emperor's attendance at the Hippodrome games, ${ }^{6}$ which consisted essentially of chariot races between the teams of the four colours, Blue, Green, White and Red, the Whites and Reds being paired with and subordinated to the other two. ${ }^{7}$ The emperor presided over the races, and rewarded the victors, from the upper story of a palace building known as the Kathisma, which contained a dining hall and a bedchamber as well as the grandstand where he and his court overlooked the arena, in full view of the people arrayed according to faction on the opposite side. Apart from the actual races, the proceedings included lengthy sets of acclamations addressed to the emperor by the two main factions, in which the chants of the cheerleaders alternated with the shouts of the crowd.

The court's day at the races as described by the Book of Ceremonies was a very tame, ritualised and infrequent affair compared with what had happened in imperial Rome, or in Constantinople four centuries earlier. The number of race days and the number of races per day had been drastically reduced; the factions no longer used their acclamations to confront the emperor with embarrassing protests or requests, and their rivalry no longer erupted into violence now that their officers were appointed and controlled by the authorities. However, the existence of these officers shows that the factions were serious organisations, with considerable responsibility for training and equipping the

${ }^{5}$ The most complete edition is still that of J.J. Reiske, Constantini Porphyrogeniti imperatoris De cerimoniis aulae byzantinae libri duo (Bonn 1829-30); Book I is edited with a French translation by A. Vogt, Constantin Porphyrogenète, Le livre des cérémonies, Livre I, 2 vols. (Paris, 1935-9; repr. 1967).

${ }^{6}$ De cerimoniis I.77-82: new edition of these chapters with French translation and extensive commentary by G. Dagron, 'L'organisation et le déroulement des courses d'après le Livre des cérémonies', Travaux et mémoires 13 (2000) pp. 1-200.

See in general Alan Cameron, Circus Factions (Oxford 1976). 
chariot teams, for composing, staging and orchestrating the chants and dances, and, presumably, for filling up the tiers of seats in the sections assigned to their supporters on the north side. The Blues and the Greens had their own churches, their own stables, and their leaders, the demarchoi, appear to have had an administrative role in two of the city's fourteen regions. At times they functioned as urban militias. Though not political, social or religious parties, it is becoming increasingly clear from other cities that the factions represented deeply rooted patterns of civic allegiance and organisation. ${ }^{8}$ Their faceto-face encounter with the emperor in the games brought court and capital together in the performance of a common ritual that marked moments of significance to both. Games were held to celebrate not only the major dates in the religious calendar and important events in the life of the imperial family, such as weddings and births, but also victories over the Empire's enemies and the most symbolically significant date in the existence of Constantinople, namely the anniversary of its foundation on 11 May 330.

The games were not the only occasions and the Hippodrome was not the only place in which the Book of Ceremonies shows court ceremonial reaching out to the public spaces of the city. Once a year, at the beginning of Lent, the emperor delivered a public speech, the silention, from the steps of a great hall called the Magnaura. ${ }^{9}$ He was surrounded by his household guards and attendants, and his audience consisted of the senior court dignitaries 'and all of the urban populace'. The Magnaura, like the Kathisma, was a Palace building, but it lay at the outer entrance to the Palace complex, opening onto a freely accessible public space, and it was not used for very exclusive functions. It had probably originated as a senate house, and apart from the yearly silention, it served mainly for the routine reception of foreign ambassadors and the convening of occasional 'parliamentary' assemblies to approve imperial policy; it also housed a law court in the ninth century, and even, for a short time, a university. ${ }^{10}$

${ }^{8}$ Charlotte M. Roueché, Performers and Partisans at Aphrodisias (London 1993); eadem, 'Looking for Late Antique Ceremonial: Ephesos and Aphrodisias', in: 100 Jahre Österreichischer Forschungen in Ephesos, Denkschriften der Österreichischen Akademie der Wissenschaften 260, H. Friesinger and F. Krinzinger, eds. (Vienna 1999) pp. 161-168.

${ }^{9}$ De cerimoniis, II.10, ed. Reiske, I, pp. 545-548.

${ }_{10}$ De cerimoniis, II.15, pp. 566-594; Cyril Mango, The Brazen House (Copenhagen 1959) pp. 57-58; Albrecht Berger, Untersuchungen zu den Patria Konstantinupoleos 
Ceremonial outreach also happened when the emperor went, on a religious feast day, to worship at a church outside the Palace. ${ }^{11}$ The most important of these venues was the Great Church of Hagia Sophia, the patriarch's cathedral, which like the Hippodrome and the Magnaura lay in close proximity to the Palace and allowed the emperor direct, exclusive access. ${ }^{12}$ This is where he attended the liturgy on the great dominical feasts of the Christmas and Easter season..$^{13}$ But the sacred calendar took the emperor to other churches in the vicinity, as well as to churches much further afield, and occasionally to other institutions, notably to the city's old-age homes, which he visited to distribute alms on Holy Thursday, ${ }^{14}$ and to the 'holy bath' at the Blachernae, where he went to bathe on certain Fridays. ${ }^{15}$ The services and receptions at these places involved a variety of personnel, both secular and clerical, who were not regularly in attendance on the emperor. Among them the representatives of the Blue and Green factions often played a prominent role. The emperor's processional route from his bedchamber to Hagia Sophia took him past alternating sets of Blue and Green militias, who acclaimed him in turn as he approached the northern exit from the Palace complex; at the first reception, they were accompanied by visiting foreigners and the city's guilds. He was then received and acclaimed by different, civilian Blues and Greens stationed between the Palace gate and the atrium of the church; on his return, the same process was repeated in reverse. ${ }^{16}$ On other occasions, between Easter and Pentecost, it was enacted over a much longer distance when the imperial cortège returned from a visit to one of three churches in

(Bonn 1988) pp. 242ff., 267 n. 207; Paul Magdalino, 'Justice and Finance in the Byzantine State, Ninth to Twelfth Centuries', in: Law and Society in Byzantium, NinthTwelfth Centuries, Angeliki Laiou and Dieter Simon, eds. (Washington, D.C. 1994) pp. 97-99.

${ }^{11}$ See in general Albrecht Berger, 'Imperial and Ecclesiastical Processions in Constantinople, in: Byzantine Constantinople: Monuments, Topography and Everyday Life, Nevra Necipoğlu, ed. (Leiden 2001) pp. 73-87.

12 Mango, Brazen House, pp. 87-91.

13 Procedure outlined mainly in the first two chapters of the Book of Ceremonies: De cerimoniis, I.1-2, ed. and trans. Vogt, I, pp. 3-34; cf. George P. Majeska, 'The Emperor in his Church: Imperial Ritual in the Church of St. Sophia', in: Byzantine Court Culture from 829 to 1204, Henry Maguire, ed. (Washington, D.C. 1997) pp. 1-11; Gilbert Dagron, Emperor and Priest. The Imperial Office in Byzantium (Cambridge 2003) pp. 84-95.

${ }^{14}$ De cer., I.42: Vogt, I, 165-6.

${ }^{15}$ De cer., II.12: Reiske, I, 551-6

${ }^{16}$ De cer., I.1: Vogt, I, 8-10, 14-15; I.2: Vogt I, 29-34 (Christmas acclamations). 
the west of the city: the Holy Apostles, ${ }^{17}$ St Mokios, ${ }^{18}$ or the Virgin of the Spring (Pege) outside the walls. ${ }^{19}$ The Blues and Greens took turns in greeting the procession at regular intervals all the way to the palace, along a route which led through the commercial heart of the city, taking in all of its important nodal points and most of its important Roman monuments, including the Forum of Constantine and the Capitolium. This route coincided more or less exactly with the triumphal avenue along which ninth- and tenth-century emperors paraded on their return from victorious campaigns. ${ }^{20}$ On these occasions, too, they were acclaimed by the factions: thus did the capital share symbolically in the emperor's victory and identify with his homecoming. The use of the same route for imperial processions on religious feasts made victory ceremonial a regular annual occurrence, as of course did the Hippodrome games associated with the birthday of Constantinople and the Christmas and Easter cycles. ${ }^{21}$

Court ceremonial involved the capital, moreover, by including the city's residents in exclusive Palace events. Only the eunuchs of the bedchamber and a few service personnel normally lived on site; all other court dignitaries normally commuted from their own urban homes. ${ }^{22}$ Apart from the privileged title-holders who regularly attended, lowlier functionaries came as occasional guests, notably to one of the great banquets held on the twelve days of Christmas in the Triclinium of the Nineteen Couches, where the diners dined reclining in the Roman style. ${ }^{23}$ On several occasions, the Blue and Green factions took part. They performed acclamations at imperial coronations and weddings,

17 I.5, 10: Vogt, I, 41-5, 65-77

${ }^{18}$ I.7, 26: Vogt, I, 48-9, 92-100.

19 I.8, 27: Vogt, I, 50-53, 101-5.

20 Constantine Porphyrogenitus, Three Treatises on Imperial Military Expeditions, J.F. Haldon, ed. and trans. (Vienna 1990) pp. 136-51; cf. Michael McCormick, Eternal Victory. Triumphal Ruldership in Late Antiquity, Byzantium and the Early Medieval West (Cambridge 1986) pp. 144-176.

${ }^{21}$ Dagron, 'L'organisation', pp. 127-132. The order of ceremony for victory games is described in De cer., II.20: Reiske, 612-5.

${ }^{22}$ Alexander P. Kazhdan and Michael McCormick, 'The Social World of the Byzantine Court', in: Byzantine Court Culture from 829 to 1204, Henry Maguire, ed. (Washington, D.C. 1997) pp. 167-197, at pp. 185-187.

${ }^{23}$ Kazhdan and McCormick, 'The Social World', pp. 175-176, 180-181, based on the Kletorologion of Phliotheos (899), a treatise concerning the order of seating at imperial banquets: Nicolas Oikonomides, ed., Les listes de préséance byzantines des IX et $X^{e}$ siècles (Paris 1972) pp. 164-189. 
and at the promotions of major dignitaries. ${ }^{24}$ This mainly happened in the older, upper parts of the palace complex which were used for state occasions. But there was one ceremony held in the new, lower palace area where the factions were the stars of the show: the deximon or parakyptikon. ${ }^{25} \mathrm{~A}$ day before the staging of games at the Hippodrome, the Greens and the Blues treated the emperor and the court to a day of song and-usually-dance. From the reign of Justinian II at the end of the seventh century, each faction was assigned its own courtyard with a central fountain on a terrace below the main halls of the lower palace. ${ }^{26}$ There, they would assemble to perform acclamations and chants accompanied by organ music as the emperor looked down on the proceedings, flanked by the court dignitaries, and framed by an awning, the parakyptikon, which was mounted on a parapet in front of his throne. ${ }^{27}$ After the ceremony had been performed in both courtyards, the emperor and a selection of dignitaries retired for lunch to the Hall of Justinian II. Depending on the occasion, the factions would either lunch separately in their courtyards, or each in turn would be ushered in turn into the dining hall after the main course, for the faction leaders to dance around the tables three times while the chanters sang acclamations. ${ }^{28}$

Inside as outside the Palace, the Blues and the Greens were not integrated with the court hierarchy; they were strictly separated by role and space from the dignitaries and household attendants who stood, walked, rode or-sometimes-sat beside the emperor. The presence of the factions at Palace festivities nevertheless served to emphasise the point made by the court's appearance at external ceremonial venues

24 De cer., I. 47-63: Vogt, II, 1-78.

25 Seven chapters of De cer. are concerned with various aspects of the deximon: I. 70-76: Vogt, II, 86-111. The description of the main event in ch. 73, pp. 94-101, associates it with the 'Golden Hippodrome', the games held in May between Easter and Pentecost, but it is clear from other chapters that this was not the only occasion (72, p. 93), and that the deximon was also held in winter, when in bad weather it would be transferred to the more sheltered courtyard of the Triconch $(75, \mathrm{p} .105)$.

${ }^{26}$ Justinian II laid out the courtyard and fountain of the Blues in 694, at about the same that he built the palace hall named after him: Theophanes, Chronographia, C. de Boor, ed. (Leipzig 1883) vol. 1, pp. 367-8; Cyril Mango and Roger Scott, trans., The Chronicle of Theophanes Confessor (Oxford 1999) p. 513. The courtyard of the Greens, which was also close to the Hall of Justinian II, cannot have been far removed in date. On both courtyards, see Rodolphe Guilland, 'Les Phiales des factions', Études de topographie de Constantinople byzantine I (Amsterdam 1969) pp. 211-6.

${ }_{27}$ For the parakyptikon, see Vogt, II, pp. 96, 99, 111.

28 Vogt, II, 101-4. 
that were either liminal, like the Hippodrome, the Magnaura, and Hagia Sophia, or fully located in public space, like the Holy Apostles, involving processional movement through the city's avenues and squares. The point was that the court was symbolically attached to the capital, and could not be detached without violating the proper, constitutional order of things, the katastasis, taxis or eutaxia that ceremonial represented, as the prefaces to the Book of Ceremonies make clear. ${ }^{29}$ Other sources for the period covered by the Book of Ceremonies, the sixth to tenth centuries, record many other occasions on which emperors appeared in public, making pragmatic as well as symbolic use of civic spaces like the Hippodrome, the Magnaura, Hagia Sophia and the processional route through the city centre. To take just one example: in 713, on the day before Pentecost, the emperor Philippikos organised a festive reception at the ancient public bath of the Zeuxippos, adjacent to the Palace. He rode in accompanied by music, dancing and acclamation, and when he had bathed-presumably in public-he feasted with "citizens of ancient lineage". Unfortunately for him, the occasion-well publicised in advance-provided perfect cover for a coup d'état. The conspirators seized him as he was enjoying his siesta, and took him to the dressing room of the Green faction, who were clearly part of the plot. Here he was blinded and held until his successor was publicly acclaimed the next day in Hagia Sophia. ${ }^{30}$

Yet the relationship between court and capital reflected in the Book of Ceremonies was changing even as that compilation was being put together in the 960s. It included material that was up to four centuries old, and in many cases where it appears to be prescribing current practice, it is in fact describing ceremonies known only from written records. This is most clearly demonstrated in the case of the receptions in the courtyards of the Blues and the Greens. The exact procedure outlined in the Book of Ceremonies could not have taken place in the tenth century, because the emperor Basil I, as we learn from his biography, had taken the fountains to adorn the atrium of the new church he had founded to the east of the Palace, and had built a bath-house in the courtyard of the Blues. ${ }^{31}$ Basil may have confined the reception ceremonies to what had previously been their winter venue, the

\footnotetext{
${ }^{29}$ Vogt, I, 1-2; Reiske, I, 516-7.

30 Theophanes, Chronographia, ed. de Boor, vol. 1, 383; trans. C. Mango and R. Scott, p. 533.

31 Theophanes Continuatus, I. Bekker, ed. (Bonn 1838) pp. 327, 336.
} 
sheltered courtyard of the Triconch in the upper Palace, ${ }^{32}$ but equally he may have done away with them altogether. Either way, many other ceremonies are likely to have suffered a similar fate, particularly those which the Book of Ceremonies sets in the upper, older parts of the Palace. These areas-corresponding effectively to the palace of Constantine and Justinian-are seldom heard of again, although the Hall of the Nineteen Couches was apparently still functioning c. $1040 .{ }^{33}$ As Cyril Mango has plausibly argued, they probably lay outside the fortification wall which the emperor Nikephoros II Phokas put up around the inhabited section of the palace between 963 and 969-thus at exactly the time when the Book of Ceremonies was being compiled. The fortification turned the Palace into "a kind of castle, called by disgruntled contemporaries a 'tyrant's acropolis" ". ${ }^{34}$ The fortified sector, which became known as the Palace of the Boukoleon, remained the principal location of the court until the late eleventh century, when the Comnenian dynasty developed the Blachernae as the favourite imperial residence.

By first retrenching within the fortified "Kremlin" of the Boukoleon Palace, and then by moving to the semi-suburban Blachernae, far from the Hippodrome, Hagia Sophia and the Forum of Constantine, the court was progressively distancing itself from the city in ways that had not existed in the period covered by the Book of Ceremonies. Yet this observation needs to be qualified. ${ }^{35}$ Games continued to be staged at the Hippodrome until the end of the twelfth century. ${ }^{36}$ The Great Palace remained the seat of government, and the financial administration, at least, was lodged in the old part of the complex, outside

\footnotetext{
${ }^{32}$ See above, n. 25.

${ }^{33}$ Michael Psellos, describing the unhappy lot of the lowly Palace bureaucrats, the asekretai, mentions that their one treat was an invitation (kletorion) to a meal where they had to eat in a reclining position: Antony Robert Littlewood, ed., Michaelis Pselli oratoria minora (Leipzig 1985) p. 46. This seems to correspond to the practice in the Hall of the Nineteen Couches as described in the Kletorologion of Philotheos, which mentions the asekretai among the 'Sandal Senate' who received invitations to two of the ten Christmas dinners: Oikonomides, Listes de préséance, pp. 169, 181.

${ }^{34}$ Cyril Mango, 'The Palace of the Boukoleon', Cahiers archéologiques 45 (1997) pp. 41-50.

${ }_{35}$ See Paul Magdalino, 'Manuel Komnenos and the Great Palace', Byzantine and Modern Greek Studies 4 (1978) pp. 101-114 [repr. in Tradition and Transformation in Medieval Byzantium (Aldershot 1991), no. V].

${ }^{36}$ Rodolphe Guilland, 'La disparition des courses', Études de topographie I, pp. 542-55.
} 
the walled Palace of the Boukoleon. ${ }^{37}$ The palace guards units were quartered where they always had been, just inside the main entrance on the northern side. New buildings were added to the Palace of the Boukoleon in the twelfth century, and emperors took up residence here on important state occasions when games were celebrated, such as coronations, triumphal homecomings, and the births and weddings of imperial children. It was important for these children to be born "in the Purple", that is in the ancient imperial birth chamber of porphyry stone. The birth of an imperial baby was announced by hanging a red, pearl-embroidered child's slipper in front of the main ceremonial entrance to the Palace, the Chalke Gate, ${ }^{38}$ just as the emperor's departure on campaign had formerly been advertised by hanging a coat of chain mail, sword and shield in the same place. ${ }^{39}$ It was in the Boukoleon Palace, too, that the emperor Manuel Komnenos convened a church council in 1166, and entertained two royal visitors, the sultan of Konya in $1161^{40}$ and the King of Jerusalem in $1171 .^{41}$

An important reason for bringing distinguished visitors to the Palace of the Boukoleon was to show them the precious and ancient imperial heirlooms kept in the palace treasuries-objects like the crowns, thrones and sceptres that had been used by Constantine and other early Byzantine emperors. ${ }^{42}$ Christian visitors like the King of Jerusalem were also given a private viewing of the sacred relics in the palace chapel, whose centrepiece was the collection of objects associated with Christ and his crucifixion. Although access to the chapel was restricted, there are good indications that it was on the tourist trail of pilgrimage sites followed by Christian travellers. ${ }^{43}$

Thus despite or indeed because of being partially abandoned by the court, the Great Palace became part of the historic, monumental fabric of the capital, a showcase of ancient and holy memorabilia and mirabilia, to be admired along with the great triumphal columns, the

37 The domed building known as the Oaton was still a fiscal archive in 1094, as it had been in the tenth century: see Paul Magdalino, Studies on the History and Topography of Byzantine Constantinople (Aldershot 2007) no. I, p. 45.

${ }_{38}$ Magdalino, Empire of Manuel, p. 243.

39 Constantine Porphyrogenitus, Three Treatises, pp. 96-97.

${ }^{40}$ John Kinnamos, Epitome, Augustus Meineke, ed. (Bonn 1836) pp. 204-206.

${ }^{41}$ William of Tyre, Chronique, R.B.C. Huygens, ed. (Turnhout 1986) pp. 943-946.

${ }_{42}$ Kazhdan and McCormick, 'The Social World of the Byzantine Court', p. 195.

${ }^{43}$ Paul Magdalino, 'L'église du Phare et les reliques de la Passion à Constantinople ( $\left.\mathrm{VII}^{e} / \mathrm{VIII}^{\mathrm{e}}-\mathrm{XIII}{ }^{\mathrm{e}} \mathrm{s}.\right)^{\prime}$ ', in: Byzance et les reliques du Christ, Jannic Durand and Bernard Flusin, eds. (Paris 2004) pp. 15-30. 
statues in the Hippodrome, Hagia Sophia and the numerous other churches and monasteries. Since at least the tenth century, visits to Hagia Sophia had been part of the treatment used to awe foreign envoys to the imperial court; ${ }^{44}$ indeed, it is hard to believe that all the great public monuments had not served this purpose from the beginning. So the capital was an indispensable instrument of 'palace diplomacy', and never more so than in the twelfth century, when the court's move to the Blachernae effectively added the Great Palace to the list of 'state heritage' sites that displayed the glories of the 'national' past.

After 1261, however, when the restored Byzantine Empire simply lacked the resources to restore Constantinople to its full pre-1204 glory, the court's return to the Blachernae did mark the beginning of an unambiguous disengagement from the life and institutions of the capital. The Hippodrome games were never revived, the Great Palace fell into ruin after 1300, and the court itself was progressively downsized by the Empire's territorial contraction and dynastic disintegration. The end result is documented by a treatise on court hierarchy and protocol written in the late fourteenth century-the only one of its kind later than the Book of Ceremonies. ${ }^{45}$ Nearly all the action described by the anonymous author, known to scholars as Pseudo-Kodinos, is limited to a single reception-cum-dining hall, with a few closely adjoining structures making occasional appearances: the imperial bedchambers, a palace church, another chapel, an elevated walkway, and a raised tribunal both overlooking a courtyard. Not only was this ceremonial space, which occupied just a part of the fortified Blachernae complex, very modest compared with the multiple halls and corridors of the Great Palace evoked by the Book of Ceremonies; it also did not provide for regular ceremonial interface between court and capital. There were no liminal spaces equivalent to Hagia Sophia, the Hippodrome and the Magnaura. On certain feast days Pseudo-Kodinos' emperor does venture out of his castle to worship at a church or monastery, sometimes at the other end of the city, and his cavalcade is an occasion for

${ }^{44}$ Theophanes Continuatus, ed. Bekker, p. 402; Samuel H. Cross and Olgerd P. Sherbowitz-Wetzor, trans., The Russian Primary Chronicle (Cambridge, Mass. 1953) p. 111.

${ }^{45}$ Jean Verpeaux, Pseudo-Kodinos, Traité des offices (Paris 1966); cf. Paul Magdalino, 'Pseudo-Kodinos' Constantinople', in: Paul Magdalino, Studies on the History and Topography of Byzantine Constantinople (Aldershot 2007) no. XII. 
people to approach him with petitions. ${ }^{46}$ But there are no Blues and Greens acclaiming him along the route, and the only rituals where the emperor is acclaimed by the people are those associated with his coronation. ${ }^{47}$

This is not to deny that acclamation was still an important feature of the festive ceremonial for the Christmas and Easter seasons, notably in the ceremony called the prokypsis. ${ }^{48}$ After their devotions in the palace chapel, the emperor and his sons proceeded to an outdoor tribunal, also called prokypsis, hung with curtains and tapestries; a curtain was drawn to reveal the emperor alone in full regalia, cut off at the knees by a balustrade that also hid the two kneeling men holding the candle and the sword both visible beside him. At his appearance, the chanters and musicians in the assembled crowd burst into songs and acclamations. Now the prokypsis ceremony has distinct echoes, in name and in form, of the old parakyptikon of the Book of Ceremonies, the emperor's 'leaning over' the acclaiming factions in their respective courtyards, which itself reproduced the ritual performed in the Hippodrome. ${ }^{49}$ But in this case, the assembly over which he 'leaned' consisted entirely of court personnel: the Varangian guard of English axebearers, the palace clergy, and the hierarchy of dignitaries, a number of whom acted as standard bearers. The only hint of a popular presence in PseudoKodinos' description lies in the mention of banners belonging to the demarchs-the traditional term for the faction leaders. Thus although the fourteenth-century prokypsis ceremony may have been the direct lineal descendant of the ninth-century parakyptikon, it differed significantly in not being a symbolic face-to-face encounter between the court and the people of the capital, and in not being the prelude to events at the Hippodrome. Now the people's place was reduced to a minimum and absorbed by the court, which took over their role as spectators and applauders of the emperor's solitary, still epiphany. It was a similar story in the banquet that followed the prokypsis. ${ }^{50}$ There were no guests; the emperor sat alone at table, with the court standing in attendance. He was served not by lowly domestic servants, but by

\footnotetext{
${ }^{46}$ Magdalino, 'Pseudo-Kodinos', pp. 172-173; cf. Ruth Macrides, 'The ritual of petition', in: Ritual in Greece: interdisciplinary perspectives, P. Roilos and D. Yatromanolakis, eds. (Cambridge, Mass. 2004) pp. 356-370.

${ }^{47}$ Verpeaux, Pseudo-Kodinos, pp. 252-253.

48 Verpeaux, Pseudo-Kodinos, pp. 195-204.

49 The connection is made by Dagron, 'L'organisation', p. 123.

${ }^{50}$ Verpeaux, Pseudo-Kodinos, pp. 207-218.
} 
noble dignitaries, bearing the high-ranking titles of Grand Domestic (megas domestikos), Domestic of the Table (domestikos tes trapezes), and Seneschal (pinkernes). Their status is clear not only from their hierarchical rank, but also from their functions and their prosopography, as documented by other sources: they belonged to the emperor's social peer group, from which leading military commanders were appointed. The Grand Domestic was indeed the ex officio commander-in-chief of the armed forces-the Marshal of the realm.

A palace consisting of a Great Hall and minor adjuncts in a castle courtyard, where household offices were ritually performed by peers of the realm: this does not look like imperial Rome or Byzantium. It looks much more like a Western medieval royal court of the eleventh and twelfth centuries. It is a striking manifestation of the evolution that Gilbert Dagron has recently highlighted in an evocative comparison of the French and Byzantine monarchies: as kingship in France took on imperial claims and attributes, the Byzantine Empire became more of a national kingdom. ${ }^{51}$ We may add that in the process, it looked east as well as west. Pseudo-Kodinos was conscious of the Persian and Assyrian heritage that the empire shared with the neighbouring Turkish powers. ${ }^{52}$ Courtiers sported Oriental as well as Western fashions ${ }^{53}$ and when the Castilian ambassador Clavijo visited the Byzantine court in 1402, he had an audience with the emperor "in his private chamber... seated on a raised dais, carpeted with small rugs, on one of which was spread a brown lion skin and at the back was a cushion of black stuff embroidered in gold". ${ }^{54}$

Another Spanish visitor around the same time, Pero Tafur, observed, “The Emperor's state is as splendid as ever, for nothing is omitted from the ancient ceremonies, but, properly regarded, he is like a Bishop without a See". ${ }^{55}$ To put it another way, Byzantium was now an imperial court and capital without an empire. Until the bitter end

\footnotetext{
${ }^{51}$ Gilbert Dagron, 'Empires royaux, royautés impériales. Lectures croisées sur Byzance et la France médiévale', Summa. Dieter Simon zum 70. Geburtstag, R.M. Kiesow, R. Ogorek, Sp. Simitis, eds. (Frankfurt 2005) pp. 81-97.

${ }^{52}$ Verpeaux, Pseudo-Kodinos, pp. 205-206, 218-219.

${ }^{53}$ Nikephoros Gregoras, Byzantina Historia I, Ludwig Schopen, ed. (Bonn 1829) pp. 567-568.

54 [Ruy Gonzalez de] Clavijo, Embassy to Tamerlane 1403-1406, G. Le Strange, trans. (London 1928) p. 61.

${ }^{55}$ Pero Tafur, Travels and Adventures 1435-1439, M. Letts, trans. (London 1926) p. 145 .
} 
came in 1453, court and capital remained indispensable to each other's imperial identity, but curiously neither depended on the other for its existence. In losing their imperial substance, they had lost the main thing they had in common, and they had lost touch. Constantinople had become the symbolic, spiritual capital of an Orthodox oikoumene, a polycentric Byzantine commonwealth of which the patriarch, not the emperor, was the effective head. The court, meanwhile, had become virtually indistinguishable from its many princely and royal neighbours, where the capital was of secondary importance. 